\title{
Influence of the type of measuring device in determining the static modulus of elasticity of concrete
}

\author{
Influência do tipo de medição na determinação \\ do módulo estático de elasticidade do concreto
}

\author{
S. S. ARAÚJO \\ suelio.araujo@gmail.com
}

G. N. GUIMARÃES b gilson@eec.ufg.br

A. L. B. GEYER c andre.geyer@hotmail.com

\begin{abstract}
This paper presents a comparative analysis of the results obtained in static modulus of elasticity tests of plain concrete cylindrical specimens. The purpose of this study is to identify and evaluate the influence of several factors involved in modulus of elasticity tests such as the strain measurement device used (dial indicators, electrical surface bonded strain gages, externally fixed strain gages and linear variation displacement transducer - LVDT), the type of concrete (Class C30 and Class C60) and cylindrical specimen size (100 mm x $200 \mathrm{~mm}$ and $150 \mathrm{~mm} \times 300 \mathrm{~mm}$ ). The modulus tests were done in two different laboratories in the Goiânia, GO region and were performed according to code ABNT NBR 8522:2008, which describes the initial tangent modulus test, characterized by strains measured at tension values of $0.5 \mathrm{MPa}$ and $30 \%$ of the ultimate load. One hundred and sixty specimens were tested with statistically satisfactory results. It was concluded that the type of strain measurement device greatly influenced the modulus of elasticity results. Tests in specimens $100 \mathrm{~mm} \times 200 \mathrm{~mm}$ showed highest statistical variation.
\end{abstract}

Keywords: concrete; specimen size; measurement; modulus of elasticity.

\section{Resumo}

Este trabalho apresenta uma análise comparativa dos resultados obtidos em ensaios do módulo estático de elasticidade realizados em corpos de prova cilíndricos de concreto simples. O objetivo é identificar e avaliar a influência de alguns fatores intervenientes nos resultados do ensaio módulo de elasticidade como o tipo de equipamento utilizado para medição de deformações (compressômetro mecânico, extensômetro elétrico de colagem superficial, extensômetro elétrico de fixação externa e transdutor diferencial de variação linear, também conhecido pela sigla em inglês - LVDT), diferentes classes do concreto (Classe C30 e Classe C60) e tamanho do corpo de prova (100 mm x 200 mm e $150 \mathrm{~mm} \times 300 \mathrm{~mm}$ ). Este ensaio foi executado em dois laboratórios da região de Goiânia, GO, conforme a ABNT NBR 8522:2008 que descreve o ensaio de módulo de elasticidade tangente inicial, caracterizando a deformabilidade do concreto submetido às tensões entre $0,5 \mathrm{MPa}$ e $30 \%$ da tensão de ruptura. Foram realizados ensaios em 160 corpos de prova considerando os resultados com desempenho estatisticamente satisfatório. Concluiu-se que o tipo de medidor de deformação influenciou significativamente os resultados de módulo de elasticidade. Os corpos de prova de dimensão $100 \mathrm{~mm}$ x $200 \mathrm{~mm}$ apresentaram resultados com as maiores dispersões.

Palavras-chave: concreto; dimensão; medidor; módulo de elasticidade.

a Masters Degree in Civil Engineering from the Federal University of Goiás, Brazil (2011), School of Civil Engineering, Research Assistanship from CNPq - National Council of Scientific and Technological Development. E-mail: suelio.araujo@gmail.com. Address: Universidade Federal de Goiás. Rua Maria Senhorinha de Jesus, Quadra 14-A, Lote 10, Setor Oriente Ville, CEP: 74.355-666 - Goiânia, GO - Brasil.

b PhD., University of Texas at Austin, USA (1988). Full Professor at the Federal University of Goiás, Brazil. E-mail: gilson@eec.ufg.br Address: Universidade Federal de Goiás, Escola de Engenharia Civil, Laboratório de Estruturas. Av. Universitária, Pça. Universitária, s/n, Setor Universitário, CEP 74640-220, Goiânia, GO - Brasil.

Doctorate in Civil Engineering from the Federal University of Rio Grande do Sul, Brazil (2001). Associate Professor II at the Federal University of Goiás. E-mail: andre.geyer@hotmail.com. Address: Universidade Federal de Goiás, Escola de Engenharia Civil, Laboratório de Materiais de Construção. Av. Universitária, Pça. Universitária, s/n, Setor Universitário, CEP 74640-220, Goiânia, GO - Brasil. 


\section{Introduction}

The use of the modulus of elasticity is frequently related to displacement and deflection calculations in the design phase of a reinforced concrete structure. The structural engineer specifies a value for the modulus of elasticity of the concrete which he uses in his calculations to satisfy serviceability limit states. This value for the modulus of elasticity will be later verified during the construction phase by the construction engineer or the concrete contractor. An incorrect verification of the modulus of elasticity can have serious consequences for the structural design, for example, excessive deflections not foreseen during the design phase.

Several factors can influence the value of the concrete's modulus of elasticity $[8,10,14]$ such as concrete compressive strength, concrete specimen casting process, loading and unloading speed of the testing apparatus, mortar content, type of strain measurement device, aggregate type and size, testing machine operator, concrete specimen size. This research had the objective to study and evaluate the influence of some of these variables on the static modulus of elasticity: influence of measurement device (dial or digital indicator, surface mounted strain gages, externally fixed strain gages or clip gages, linear variable differential transformer - LVDT), concrete type (Class C30 and Class C60) and cylindrical specimen size (100 mm x 200 $\mathrm{mm}$ e $150 \mathrm{~mm} \times 300 \mathrm{~mm}$ ). Tests were conducted in two different concrete laboratories in the Goiânia, GO region.

The modulus of elasticity can be defined as a relation between the applied stress and the measured strain below yield stress. According to code ABNT NBR8522:2008 [3], the static modulus of elasticity for a concrete loaded in axial compression is determined by the inclination of the stress-strain curve obtained in testing cylindrical concrete specimens. The specimen is subjected to incrementally increasing loads and the strain is measured at each load increment. The types of modulus of elasticity are related to different loading stages and should be chosen based on the purpose of the test. Figure 1 shows the different types of static modulus of elasticity in concrete subjected to compression.

\section{Figure 1 - Different types of modulus of elasticity in the stress-strain curve}

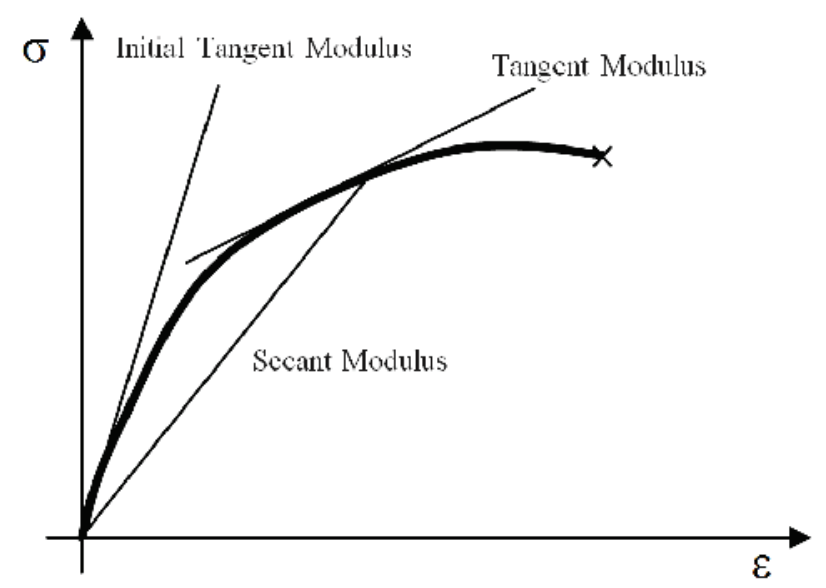

Briefly, the moduli of elasticity are:

- Initial tangent modulus: is given by the inclination of a tangent line at the origin of the stress-strain diagram. It is used to characterize concrete deflections at very low stresses.

- Tangent modulus at a given stress: is the inclination of a tangent line of the stress-strain diagram at any given stress. It is used to simulate the structure to loading or unloading at different loading stages. Loading and unloading can be applicable, for example, when a numerical structural analysis is needed due to large accidental loads.

- Secant modulus: is given by the inclination of a secant line obtained between any two points in the stress-strain diagram. Frequently the points chosen correspond to a stress of $0.5 \mathrm{MPa}$ and a stress at $50 \%$ of the ultimate stress. In this case, it simulates the structure during its initial loading stage when permanent loads prevail. The Brazilian Code for Design and Execution of Reinforced Concrete Constructions ABNT NBR 6118:2003 [4] proposes a value for the secant modulus as $85 \%$ of the initial tangent modulus. The secant modulus is frequently used by structural engineers in design.

In this work, the initial tangent modulus of elasticity was determined. It was done according to code ABNT NBR 8522:2008 [3] which prescribes, in this case, concrete strains at stress levels of $0.5 \mathrm{MPa}$ and $30 \%$ of ultimate stress. This code prescribes an initial stress of $0.5 \mathrm{MPa}$, and not a zero value, to minimize the effect of specimen imperfections, testing machine variability and the accommodation process of the top and bottom plates of the testing machine, since these factors can generate in initial disturbance in the stress-strain diagram near zero stress.

The value of the initial tangent modulus of elasticity, $E_{c i}$, is given by the equation below:

$$
\mathbf{E}_{\mathrm{ci}}=\left(\sigma_{\mathrm{b}}-\sigma_{\mathrm{a}}\right) /\left(\varepsilon_{\mathrm{b}}-\varepsilon_{\mathrm{a}}\right)
$$

where:

$\sigma_{b}$ is the higher stress and it is equal to 0.3 of the rupture stress; $\sigma_{a}$ is the basic stress and is equal to $0.5 \mathrm{MPa}$;

$\varepsilon_{b}$ is the average strain of the specimen under the higher stress; $\varepsilon_{\text {a }}$ is the average strain of the specimen under the basic stress; Contrary to strain measurements in steel rebars, strain measurements in concrete are much harder to obtain. In steel, strain measuring devices known as strain gages are widely used and give good quality and reliable results. But in concrete, the same does not happen and several researchers $[6,7,8,9]$ and laboratories in Brazil and worldwide have search for other alternatives to obtain reliable strain measures with less statistical variability. Among these alternatives for measuring strains in concrete, the present research work verified the use of four different measuring devices $[15,16]$ : dial indicator, surface bonded strain gages, externally fixed strain gages or clip gages, linear variable differential transformer - LVDT.

The digital or dial indicator is a mechanical measuring device where a small piston moves indicating the measurement. Both the strain gage and the clip gage work based on the same principle of changes in the electrical resistance of a coil during the deformation of the body to which they are attached. The difference is that the strain gage is bonded (glued) to the body surface and the clip gage 
Figure 2 - Dial Indicators (a) Strain gage (b), Clip gage (c) and LVDT (d)
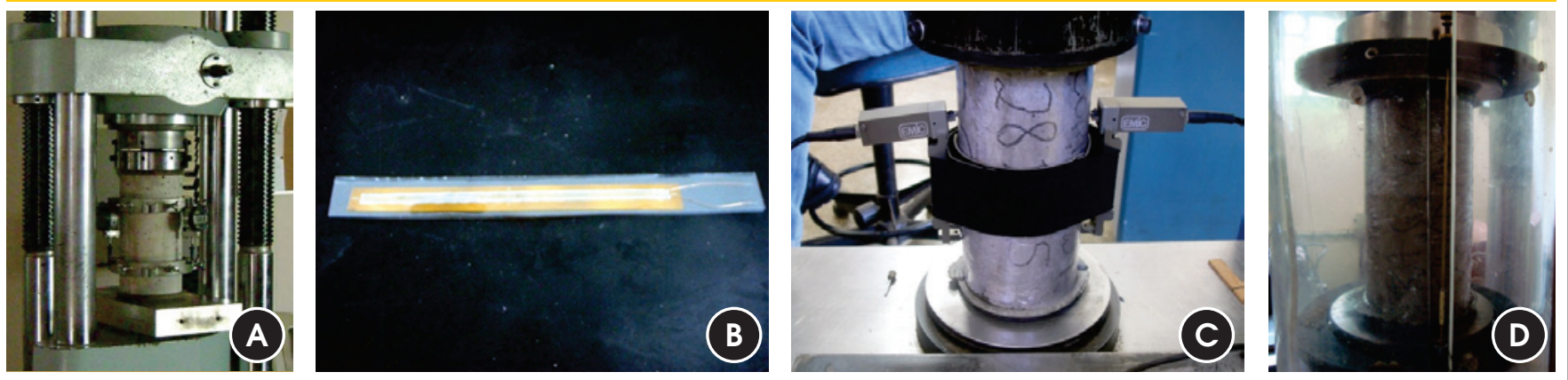

is mechanically fixed to the surface through claws, permitting their reuse. The strain gage is disposable after the test. The linear variable differential transformer is better known by its acronym LVDT and it is an electro-magnetic displacement transducer. Figure 2 shows photos of these 4 measuring devices.

As far as loading speed, code ABNT NBR 8522:2008 [3] specifies a loading speed for the modulus of elasticity test at $(0.45 \pm 0.15)$ $\mathrm{MPa} / \mathrm{s}$. The laboratory where the test is undertaken chooses the loading speed. In the research, the loading speed used was 0.6 $\mathrm{MPa} / \mathrm{s}$ at both labs.

\section{Experimental program}

Considering the characteristics of the interlaboratory program, three variables were considered:

- Type of conventional concrete (class C30 and class C60);

- Type of strain measurement device (dial gages, strain gages, clip gages and linear variation displacement transducer - LVDT);

- Cylindrical specimen dimensions: $100 \mathrm{~mm}$ x $200 \mathrm{~mm}$ and 150 $\mathrm{mm} \times 300 \mathrm{~mm}$.

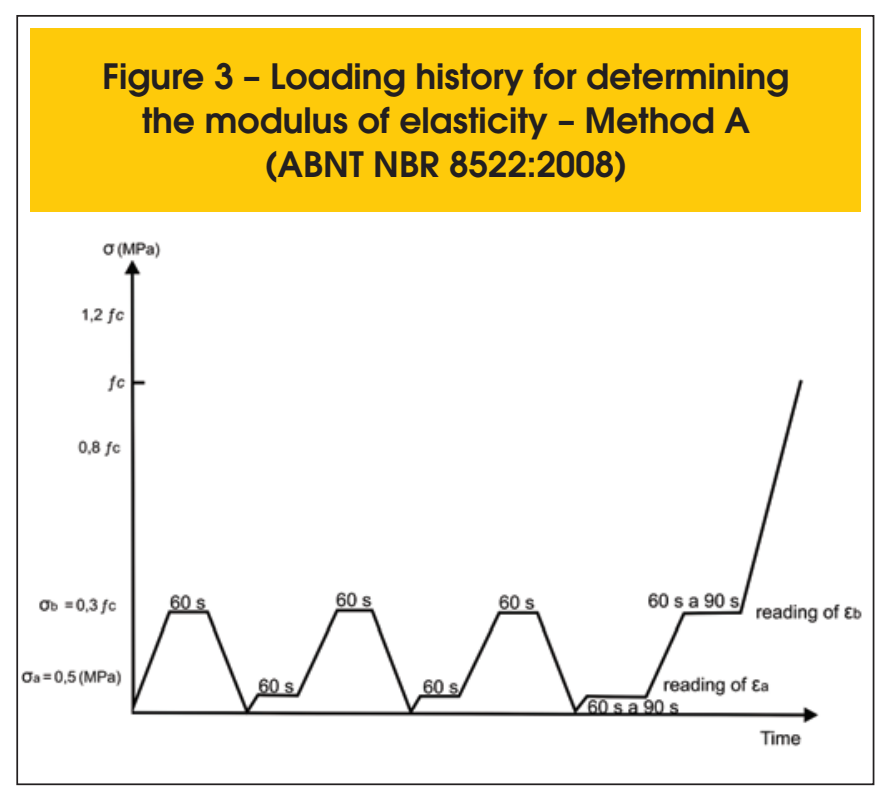

Tests with the dial gages and strain gages were done at Carlos Campos Laboratories and tests with clip gages and LVDTs were done at Furnas Centrais Elétricas Laboratories. It was not possible to conduct all tests at the same laboratory due to physical and operational constraints (equipment, operating hours, operator availability, storage) of the two laboratories involved and the quantity of specimens to be tested.

The loading stages known as Metodology A in code ABNT NBR 8522:2008 [3] was used for the modulus of elasticity tests. Cycles of loading and unloading were done. According to Figure 3, strain measurements were taken at stress levels of $0.50 \mathrm{MPa}$ and $30 \%$ of the rupture stress (known as $f_{c}$ ) and the initial tangent modulus was calculated according to Equation 1.

Conventional concrete Class $\mathrm{C} 30$ and Class $\mathrm{C} 60$ were used. These were cast in concrete mixers with a maximum capacity of 450 liters using Portland cement Type V ARI (high initial strength) fabricated by CIMPOR. Silica fume, superplasticizers and polyfunctional additives were also used in the concrete mix. The properties of the additives and admixtures used are presented in Table 1. The mix proportions are presented in Tables 2 and 3. All specimens were cast at Carlos Campos Laboratories.

Ten cylindrical specimens were cast for compressive strength tests for each type of concrete (class C30 and C60), for each specimen dimension (100 mm x $200 \mathrm{~mm}$ e $150 \mathrm{~mm} \times 300 \mathrm{~mm}$ ) and for each laboratory, for a total of 80 specimens. These tests were done in the two laboratories ( 40 specimens tested in each laboratory) at 28 days after casting. The compressive strength test is needed prior to the modulus tests so the value of $30 \%$ of rupture stress can be calculated for use in the modulus tests and in Equation 1. The rupture stress was calculated as the average of the rupture stresses of the 10 specimens.

Ten cylindrical specimens were cast for the modulus of elasticity tests for each measurement device (4 different devices), for each type of concrete (class C30 and C60), and for each specimen dimension (100 mm x $200 \mathrm{~mm}$ e $150 \mathrm{~mm} \times 300 \mathrm{~mm}$ ), for a total of $160(10 \times 4 \times 2 \times 2)$ specimens. Tests using the dial indicators and strain gages were done simultaneously on the same concrete specimen, so not all specimens cast were used. This was possible, since, during the test, the analogical readings from the dial indicators were obtained visually by the operator, and the strain gage readings were digital and obtained using a microcomputer.

All tests were done 28 days after casting. The modulus test is nondestructive and the same specimen was then taken to rupture to 


\section{Table 1 - Properties of additives and additions used in the concrete}

\begin{tabular}{cccc}
\hline Properties & Additive & Material & \\
& GLENIUM 51 & Additive & Sillica Fume Silmix \\
Main Function: & $\begin{array}{c}\text { 3rd Generation } \\
\text { Superplasticizer }\end{array}$ & $\begin{array}{c}\text { Polifuncitonal } \\
\text { Additive }\end{array}$ & Filler \\
Chemical Basis & Policarboxilate & $\begin{array}{c}\text { Sodium } \\
\text { Lignosulfonate }\end{array}$ & Amorphous Silica \\
Appearance: & Viscous Liquid & Liquid & Powder \\
Color: & Beige & Dark brown & Light or dark gray \\
Density $\left(\mathrm{g} / \mathrm{cm}^{3}\right)$ & 1.067 to 1.107 & 1.13 to 1.17 & 2.2 \\
$\mathrm{pH}:$ & 5 to 7 & 4 to 6 & 8 to 10 \\
\hline
\end{tabular}

obtain its compressive strength. The objective of testing the same specimen for compressive strength after the modulus test is to verify the homogeneity of the concrete and to allow statistical control. However, these compressive strength results were not used in Equation 1. The values used were obtained in the compressive strength tests mentioned earlier.

Specimens were cast and stored according to provisions in code
ABNT NBR 5738:2008 [1], following guidelines in code ABNT NBR 5739:2007 [2]. To reduce the influence of specimen humidity, after 24 hours after casting, the specimens were identified and stored in water tanks for 28 days. After this, the specimens were removed from the storage tanks and stored at room temperature and humidity. Sulfur capping was used in all specimens.

The specimens were grouped in packages of 10 specimens and

\section{Table 2 - Concrete $\mathrm{mix}$ for $\mathrm{fc}=30 \mathrm{MPa}$}

\section{Material Proportioning by $\mathrm{m}^{3}$ of concrete Mix design ( $1: 3.78: 4.23$ ) \\ $\mathrm{W} / \mathrm{C}$ ratio $=0.73$}

\section{Materials}

Cement CP V ARI

Artificial sand

Gravel size 1 (19 mm)

Water

Polyfuncitonal Additive

Superplasticizer

Silica Fume

Fresh

Properties:

Consistency

Air
Conventionally Vibrated Concrete Quantity per $\mathrm{m}^{3}$

$236 \mathrm{~kg}$
$891 \mathrm{~kg}$
$999 \mathrm{~kg}$
$172 \mathrm{~kg}$

$1.65 \mathrm{~kg}(0.7 \%$ of cement)

$0.94 \mathrm{~kg}(0.4 \%$ of cement)

$18.9 \mathrm{~kg}$ (as replacement for $8 \%$ of cement in weight)

\section{Concrete \\ $130 \mathrm{~mm}$ \\ $2 \%$}




\section{Table 3 - Concrete $\mathrm{mix}$ for fc $=60 \mathrm{MPa}$}

\begin{tabular}{|c|c|}
\hline \multicolumn{2}{|c|}{$\begin{array}{c}\text { Material Proportioning by } \mathrm{m}^{3} \text { of concrete } \\
\text { Mix design }(1: 1.928: 2.58) \\
\text { W/C ratio }=0.42\end{array}$} \\
\hline Materials & $\begin{array}{l}\text { Conventionally Vibrated Concrete } \\
\text { Quantity per } \mathrm{m}^{3}\end{array}$ \\
\hline Cement CP V ARI & $398 \mathrm{~kg}$ \\
\hline Artificial sand & $765 \mathrm{~kg}$ \\
\hline Gravel size 1 (19 mm) & $1028 \mathrm{~kg}$ \\
\hline Water & $167 \mathrm{~kg}$ \\
\hline Polyfuncitonal Additive & $2.79 \mathrm{~kg}$ ( $0.7 \%$ of cement) \\
\hline Superplasticizer & 1.59 kg (0.4\% of cement) \\
\hline Silica Fume & $\begin{array}{l}31.87 \mathrm{~kg} \text { (as replacement } \\
\text { for } 8 \% \text { of cement in weight) }\end{array}$ \\
\hline $\begin{array}{l}\text { Fresh } \\
\text { Properties: }\end{array}$ & Concrete \\
\hline Consistency & $120 \mathrm{~mm}$ \\
\hline Air & $1.5 \%$ \\
\hline
\end{tabular}

were randomized before the modulus of elasticity tests. Randomization was done to allow minimization of certain variables effects that could not or were not considered in the experiment such as: casting process, aggregate distribution in the concrete, testing device setup, among others. Also, if any dependency mechanism exists between subsequent experimental results, the randomizations of the tests allow this dependency to be diluted among all studied situations, thus not favoring a certain situation over another.

Statistical analysis of variance technique (ANOVA) was applied using software Statsoft Statistica $7^{\circledR}$, for concrete Class C30 and for concrete Class C60 specimens, separately and together. The test methodology consists in the application of Fisher's Test. This analysis indicated that the results should be analyzed together to be statistically significant.

\section{Presentations and discussion of results}

In order to verify the homogeneity of the concrete used, the compressive strength results of the specimens taken to rupture right after the modulus of elasticity tests were first analyzed. These compressive strength results were analyzed by statistical methods in order to identify possible variances of the results and to verify the normal distribution (histogram) of the results. Figures 4 and 5 show the histograms of these compressive strength results for concrete classes C30 and C60, respectively. Concrete C30 showed an average compressive strength of $36.5 \mathrm{MPa}$ with a coefficient of variation of $10 \%$ and concrete $\mathrm{C} 60$ showed an average compressive strength of $69.3 \mathrm{MPa}$ with a coefficient of variation of $11 \%$.
The comparison between the histograms and the normal distribution curve was analyzed by the Kolmogorov-Smirnov e Qui-square methods. From a statistical point of view, a value of $10 \%$ is an acceptable level for variability for a measuring process.

Table 4 presents the averages, standard deviations and coefficients of variation of the results obtained in all of the situations studied with a $95 \%$ confidence interval from the average for the modulus of elasticity property. A statistical analysis of variance (ANOVA) was done with the modulus of elasticity results to determine the statistically significant factors with a $95 \%$ confidence level. Some values were removed, since they did not fit the confidence interval and they were eliminated by the Chauvenet criteria.

Table 4 shows that the measuring devices that presented the smallest dispersions were the strain gages and the clip gages since the total coefficients of variation of these devices were $11.0 \%$ and $14.4 \%$, respectively, and the total coefficients of variation of the dial indicators and the LVDTs were $16.1 \%$ and $18.2 \%$, respectively.

Table 4 also shows that the specimens with $100 \mathrm{~mm} \times 200 \mathrm{~mm}$ dimensions presented higher dispersion of results, because their total coefficient of variation was $24.4 \%$ and the total coefficient of variation of the specimens with $150 \mathrm{~mm} \times 300 \mathrm{~mm}$ dimensions was $13.1 \%$.

Since ANOVA revealed that the specimen size, type of measuring device and type of concrete were statistically significant, grouping homogeneous averages by the Duncan method was done to observe the differences and similarities of the results obtained.

This method demonstrated that the two specimen sizes influenced the values of the modulus of elasticity of the concrete because the 
Figure 4 - Histogram of the compressive strength results obtained from concrete class C30 specimens

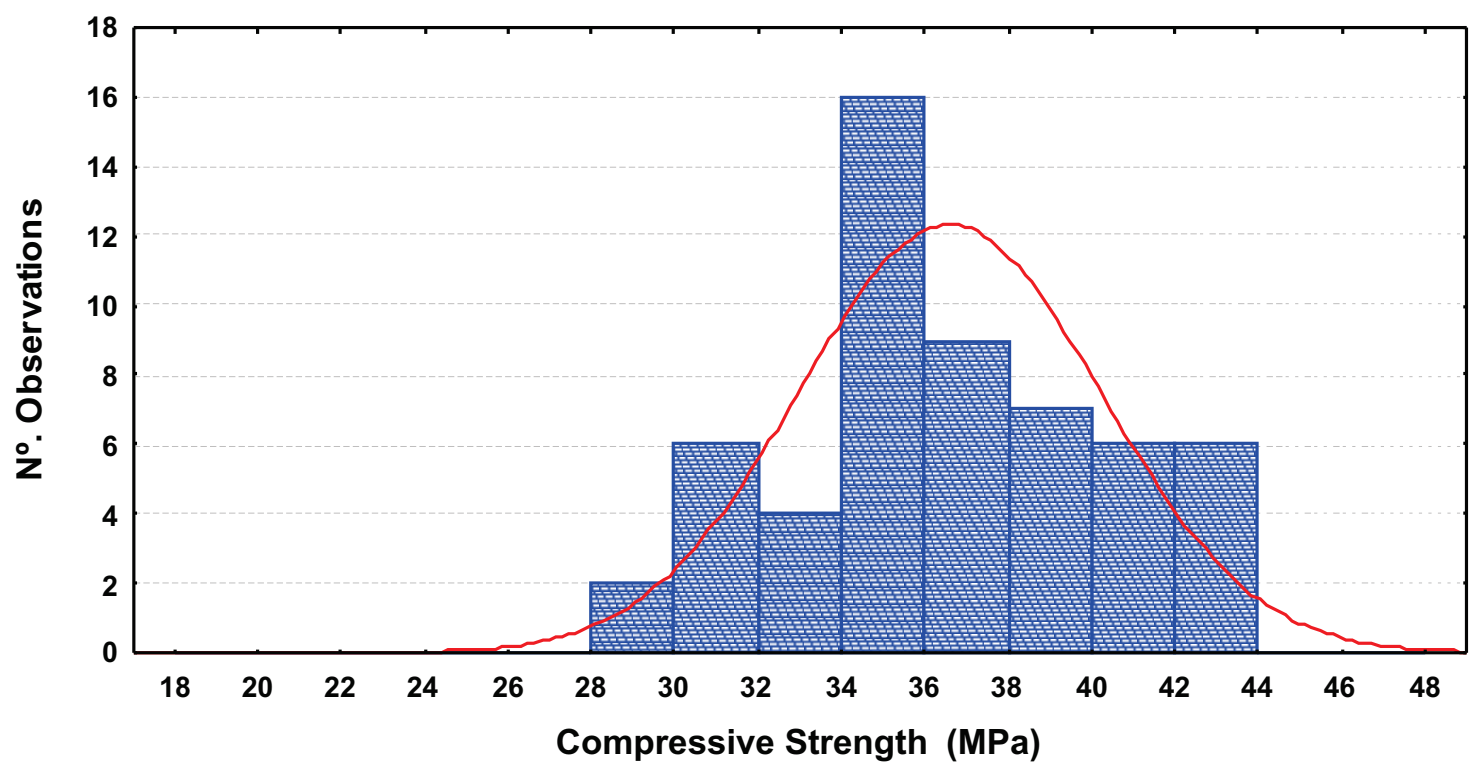

average of the modulus for specimens $100 \mathrm{~mm} \times 200 \mathrm{~mm}$ and 150 $\mathrm{mm} \times 300 \mathrm{~mm}$ were $24.4 \mathrm{GPa}$ e $26.2 \mathrm{GPa}$, respectively. That is, the specimens $150 \mathrm{~mm} \times 300 \mathrm{~mm}$ had an average $7 \%$ higher than the average obtained for specimens $100 \mathrm{~mm} \times 200 \mathrm{~mm}$.

The Duncan method also demonstrated that the strain gages presented results similar to the dial indicators, since their averages for

\section{Figure 5 - Histogram of the compressive strength results obtained from concrete class $\mathrm{C} 60$ specimens}

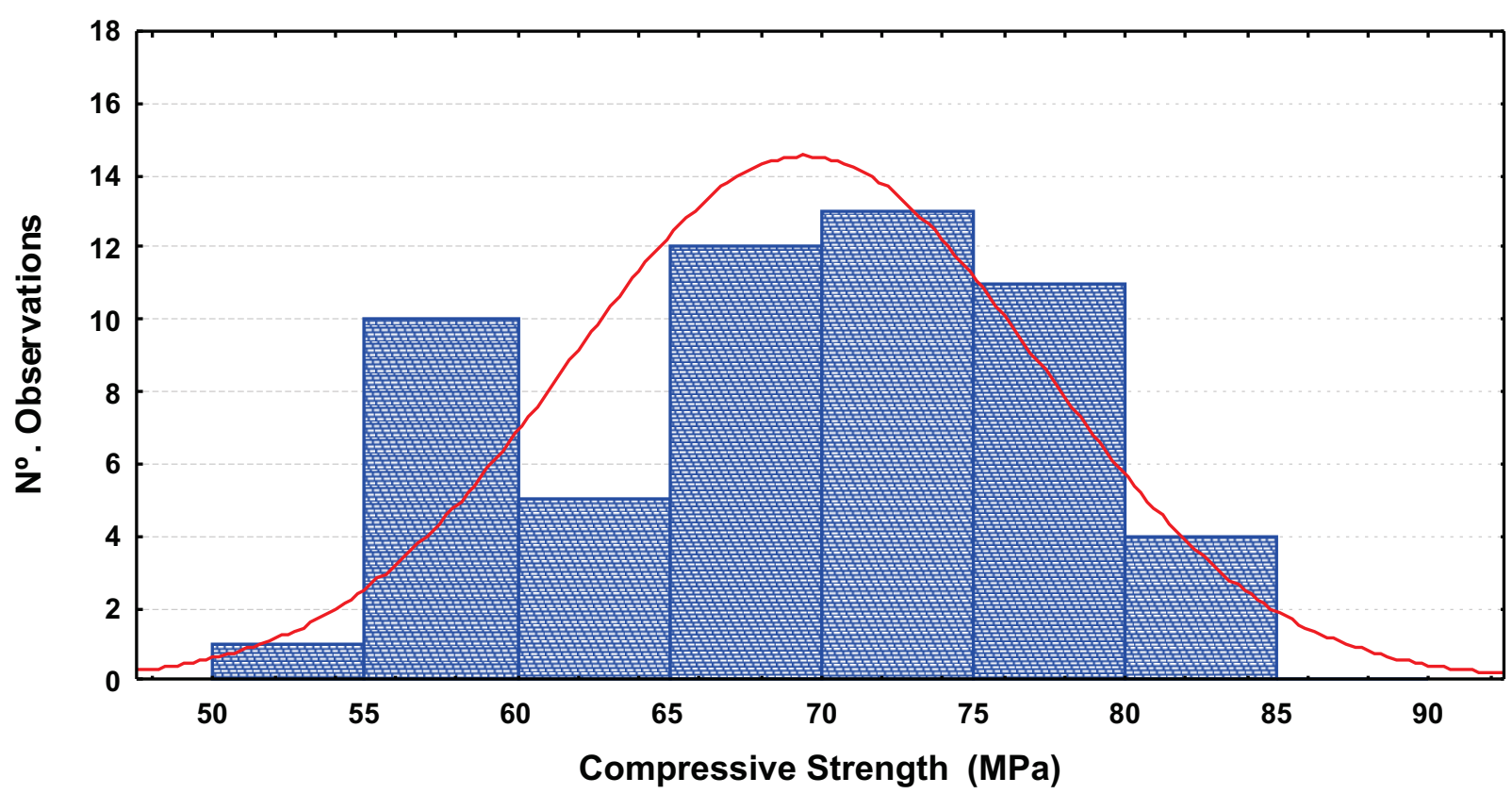


the modulus tests were $27.6 \mathrm{GPa}$ e $27.5 \mathrm{GPa}$, respectively, and the averages for the clip gages and the LVDTs were $26.3 \mathrm{GPa}$ e $19.8 \mathrm{GPa}$ respectively.

For $100 \mathrm{~mm}$ x $200 \mathrm{~mm}$ specimens, modulus results (see Figure 6) obtained using strain gages had averages of $24.6 \mathrm{GPa}$ and 30.6 GPa and their respective coefficients of variation were $13.2 \%$ and $1.9 \%$ for concrete classes $\mathrm{C} 30$ and C60. Results obtained with dial indicators had averages of $24.1 \mathrm{GPa}$ and $31.6 \mathrm{GPa}$ and their respective coefficients of variation were $16.1 \%$ and $17.7 \%$ for concrete classes $\mathrm{C} 30$ and $\mathrm{C} 60$. Results obtained with clip gages had averages of $22.0 \mathrm{GPa}$ and $29.8 \mathrm{GPa}$ and their respective coefficients of variation were $4.0 \%$ and $2.5 \%$ for concrete classes C30 and C60. Results obtained with LVDTs had averages of $14.9 \mathrm{GPa}$ and $20.3 \mathrm{GPa}$ and their respective coefficients of variation were
$13.5 \%$ and $7.9 \%$ for concrete classes C30 and C60. For $100 \mathrm{~mm} x$ $200 \mathrm{~mm}$ specimens, modulus results obtained from dial indicators and LVDTs presented larger variability.

For $150 \mathrm{~mm}$ x $300 \mathrm{~mm}$ specimens, modulus results (see Figure 6) obtained using strain gages had averages of $26.6 \mathrm{GPa}$ and 29.8 $\mathrm{GPa}$ and their respective coefficients of variation were $2.6 \%$ and $4.0 \%$ for concrete classes $\mathrm{C} 30$ and C60. Results obtained with dial indicators had averages of $26.9 \mathrm{GPa}$ and $27.9 \mathrm{GPa}$ and their respective coefficients of variation were $3.8 \%$ and $7.6 \%$ for concrete classes $\mathrm{C} 30$ and $\mathrm{C} 60$. Results obtained with clip gages had averages of $23.5 \mathrm{GPa}$ and $30.8 \mathrm{GPa}$ and their respective coefficients of variation were $4.1 \%$ and $1.5 \%$ for concrete classes C30 and C60. Results obtained with LVDTs had averages of $20.6 \mathrm{GPa}$ and $23.2 \mathrm{GPa}$ and their respective coefficients of variation were $1.4 \%$

\section{Table 4 - Statistical analysis of test results - static modulus of elasticity}

\begin{tabular}{|c|c|c|c|c|c|c|}
\hline \multicolumn{3}{|c|}{ Situation of Study } & \multirow[b]{2}{*}{$\begin{array}{c}\mathrm{N}^{\circ} \text { of } \\
\text { Specimen }\end{array}$} & \multicolumn{3}{|c|}{ Static Modulus of Elasticity (GPa) } \\
\hline $\begin{array}{l}\text { Size } \\
(\mathrm{mm})\end{array}$ & Type of strain measurement device & $\begin{array}{l}\text { Type of } \\
\text { Concrete }\end{array}$ & & $\begin{array}{c}\text { Average } \\
(\mathrm{GPa})\end{array}$ & $\begin{array}{l}\text { Standard } \\
\text { Deviation } \\
\text { (GPa) }\end{array}$ & $\begin{array}{c}\text { Coefficient } \\
\text { of Variation } \\
(\%)\end{array}$ \\
\hline- & Dial Indicators & - & 37 & 27.5 & 4.4 & 16.1 \\
\hline- & Electrical Surface Bonded Strain Gages & - & 35 & 27.6 & 3.05 & 11.0 \\
\hline- & Externally Fixed Strain Gages & - & 39 & 26.3 & 3.8 & 14.4 \\
\hline- & Linear Variation Displacement Transducer - LVDT & - & 37 & 19.8 & 3.6 & 18.2 \\
\hline $100 \times 200$ & - & - & 73 & 24.4 & 5.96 & 24.4 \\
\hline $150 \times 300$ & - & - & 75 & 26.2 & 3.4 & 13.1 \\
\hline \multirow{8}{*}{$100 \times 200$} & Dial Indicators & $\mathrm{C} 30$ & 10 & 24.1 & 3.9 & 16.1 \\
\hline & Dial Indicators & $\mathrm{C} 60$ & 9 & 31.6 & 5.6 & 17.7 \\
\hline & Electrical Surface Bonded Strain Gages & C30 & 10 & 24.6 & 3.2 & 13.2 \\
\hline & Electrical Surface Bonded Strain Gages & $\mathrm{C} 60$ & 6 & 30.6 & 0.58 & 1.9 \\
\hline & Externally Fixed Strain Gages & $\mathrm{C} 30$ & 10 & 22.0 & 0.88 & 4.0 \\
\hline & Externally Fixed Strain Gages & C60 & 9 & 29.8 & 0.74 & 2.5 \\
\hline & Linear Variation Displacement Transducer - LVDT & $\mathrm{C} 30$ & 9 & 14.9 & 2.004 & 13.5 \\
\hline & Linear Variation Displacement Transducer - LVDT & C60 & 10 & 20.3 & 1.6 & 7.9 \\
\hline \multirow{8}{*}{$150 \times 300$} & Dial Indicators & $\mathrm{C} 30$ & 9 & 26.9 & 1.02 & 3.8 \\
\hline & Dial Indicators & $\mathrm{C} 60$ & 9 & 27.9 & 2.1 & 7.6 \\
\hline & Electrical Surface Bonded Strain Gages & $\mathrm{C} 30$ & 9 & 26.6 & 0.69 & 2.6 \\
\hline & Electrical Surface Bonded Strain Gages & C60 & 10 & 29.8 & 1.2 & 4.0 \\
\hline & Externally Fixed Strain Gages & $\mathrm{C} 30$ & 10 & 23.5 & 0.96 & 4.1 \\
\hline & Externally Fixed Strain Gages & $\mathrm{C} 60$ & 10 & 30.1 & 0.46 & 1.5 \\
\hline & Linear Variation Displacement Transducer - LVDT & $\mathrm{C} 30$ & 8 & 20.6 & 0.29 & 1.4 \\
\hline & Linear Variation Displacement Transducer - LVDT & C60 & 10 & 23.2 & 2.9 & 12.6 \\
\hline
\end{tabular}


and $12.6 \%$ for concrete classes C30 and C60. For $150 \mathrm{~mm} \times 500$ $\mathrm{mm}$ specimens, modulus results obtained from dial indicators and LVDTs presented larger variability. Results obtained using LVDTs presented lowest modulus.

Since $100 \mathrm{~mm} \times 200 \mathrm{~mm}$ specimens showed larger variability in the modulus results, the variable "specimen size" was investigated in further with more results shown in Figures 7 and 8 . Figure 7 shows the effect of specimen size and the effect of concrete type with concrete class $\mathrm{C} 60$ showing higher modulus results. Modulus results obtained with $100 \mathrm{~mm} \times 200 \mathrm{~mm}$ specimens had averages of 21.6 $\mathrm{GPa}$ and $27.6 \mathrm{GPa}$ and their respective coefficients of variation were $21.6 \%$ and $20.5 \%$ for concrete classes $\mathrm{C} 30$ and $\mathrm{C} 60$. Modulus results obtained with $150 \mathrm{~mm} \times 300 \mathrm{~mm}$ specimens had averages of $24.5 \mathrm{GPa}$ and $27.7 \mathrm{GPa}$ and their respective coefficients of variation were $10.8 \%$ and $12.2 \%$ for concrete classes C30 and C60.

Figure 8 show the effect of measuring device interacting with specimen size and the behavior explained earlier is the same. Again, highest variability is shown in results obtained with LVDTs. For $100 \mathrm{~mm} \times 200 \mathrm{~mm}$ specimens, modulus results (see Figure 8) obtained using strain gages had an average of $26.8 \mathrm{GPa}$ and the coefficient of variation was $14.7 \%$. Results obtained with dial indicators had an average of $27.7 \mathrm{GPa}$ and the coefficient of varia- tion was $21.9 \%$. Results obtained with clip gages had an average of $25.7 \mathrm{GPa}$ and the coefficient of variation was $15.9 \%$. Results obtained with LVDTs had an average of $17.7 \mathrm{GPa}$ and the coefficient of variation were $18.5 \%$. For $100 \mathrm{~mm} \times 200 \mathrm{~mm}$ specimens, modulus results obtained from dial indicators and LVDTs presented larger variability.

For $150 \mathrm{~mm} \times 300 \mathrm{~mm}$ specimens, modulus results (see Figure 8) obtained using strain gages had an average of $28.3 \mathrm{GPa}$ and the coefficient of variation was $6.6 \%$. Results obtained with dial indicators had an average of $27.4 \mathrm{GPa}$ and the coefficient of variation was $6.2 \%$. Results obtained with clip gages had an average of $26.8 \mathrm{GPa}$ and the coefficient of variation was $12.9 \%$. Results obtained with LVDTs had an average of $22.0 \mathrm{GPa}$ and the coefficient of variation were $11.3 \%$. For $150 \mathrm{~mm} \times 300 \mathrm{~mm}$ specimens, modulus results obtained from clip gages and LVDTs presented larger variability.

\section{Conclusion}

The analysis of the results obtained before considered the influence of measuring device, concrete class and specimen size. The most important conclusions of this study were:

\section{Figure 6 - Static modulus of elasticity versus specimen size, type of concrete and strain measurement device}
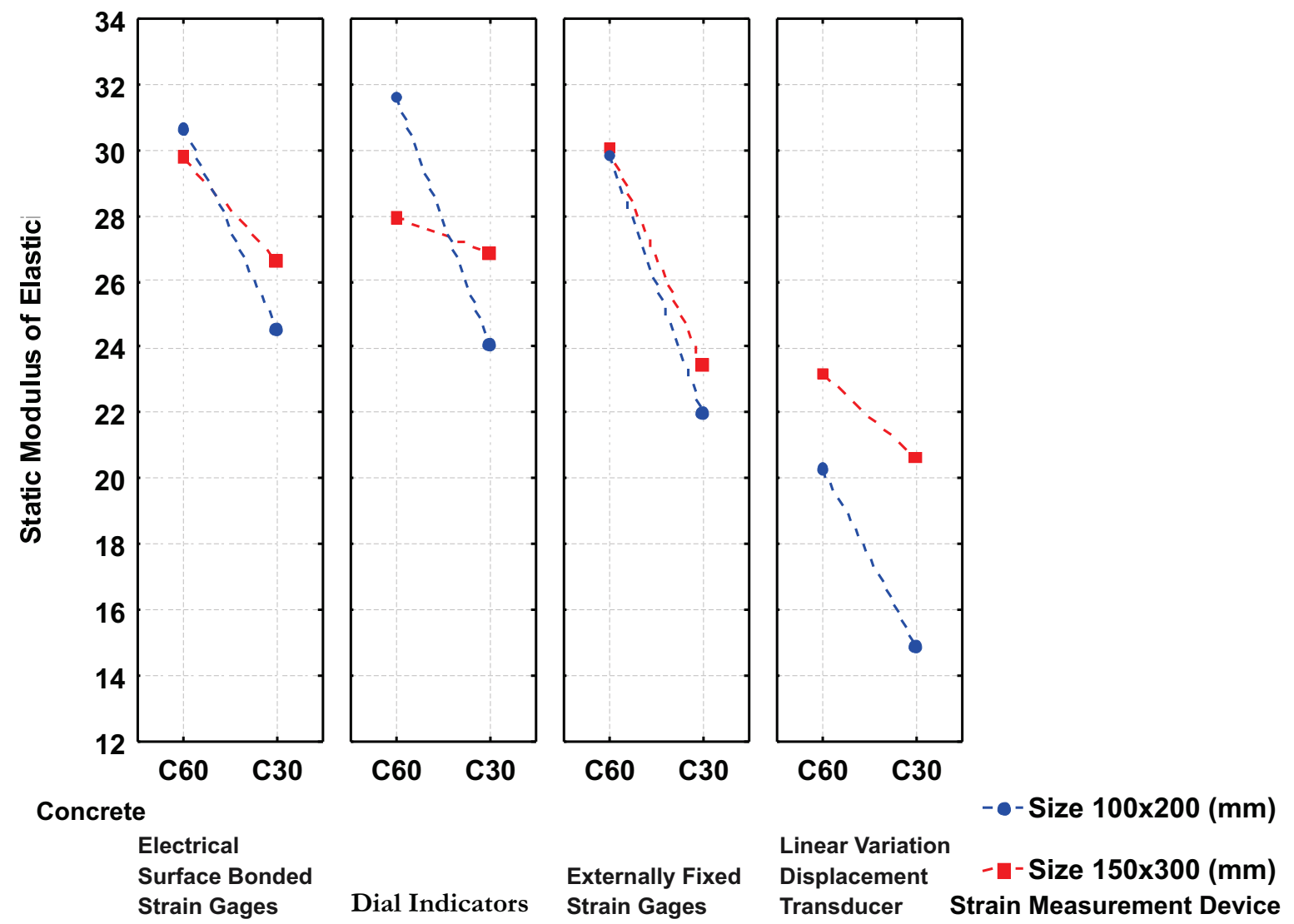
Figure 7 - Modulus of elasticity versus concrete type and specimen size (includes all measuring devices)

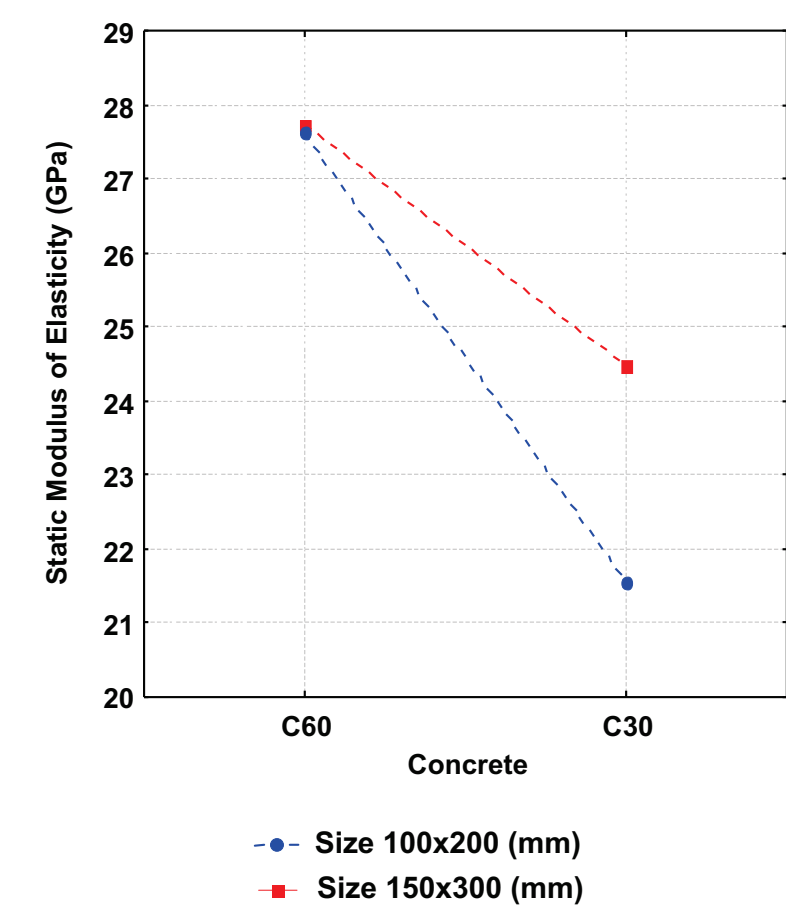

1. The two specimen sizes used in this study had an effect on the concrete static modulus of elasticity since the average modulus obtained from $100 \mathrm{~mm} \times 200 \mathrm{~mm}$ and $150 \mathrm{~mm} \times 300 \mathrm{~mm}$ specimens were $24.4 \mathrm{GPa}$ and $26.2 \mathrm{GPa}$, respectively. The average modulus obtained from $150 \mathrm{~mm} \times 300 \mathrm{~mm}$ specimens were $7 \%$ higher. However, code ABNT NBR 8522:2008 [3] sets tolerance limits in item 8.2 which allows variation in results of up to $10 \%$.

2. Results using strain gages were similar to results using dial gages since their average modulus were 27.6 GPa and 27.5 $\mathrm{GPa}$, respectively. The results for clip gages and LVDTs showed average modulus of $26.3 \mathrm{GPa}$ and $19.8 \mathrm{GPa}$, respectively.

3. For specimen size $100 \mathrm{~mm} \times 200 \mathrm{~mm}$, results showed largest variability when dial gages and LVDTs were used. For $150 \mathrm{~mm}$ $\times 300 \mathrm{~mm}$ specimens, modulus results obtained from clip gages and LVDTs presented larger variability.

4. For the two concrete types, $100 \mathrm{~mm} \times 200 \mathrm{~mm}$ specimen results showed larger variability than $150 \mathrm{~mm}$ x $300 \mathrm{~mm}$ specimen results. The $150 \mathrm{~mm} \times 300 \mathrm{~mm}$ specimens had smaller coefficient of variability in the modulus tests.

5. Modulus values obtained using dial gages and strain gages were higher than results obtained with clip gages and much higher than those obtained with LVDTs.

6. Values obtained with LVDT were smallest than those obtain with the other 3 devices. In general, LVDT was considered the less accurate (greatest coefficient of variation among the 4 de-
Figure 8 - Modulus of elasticity versus strain measurement device and specimen size (SG - strain gage, DI - dial indicator, CG - clip gage and LVDT)

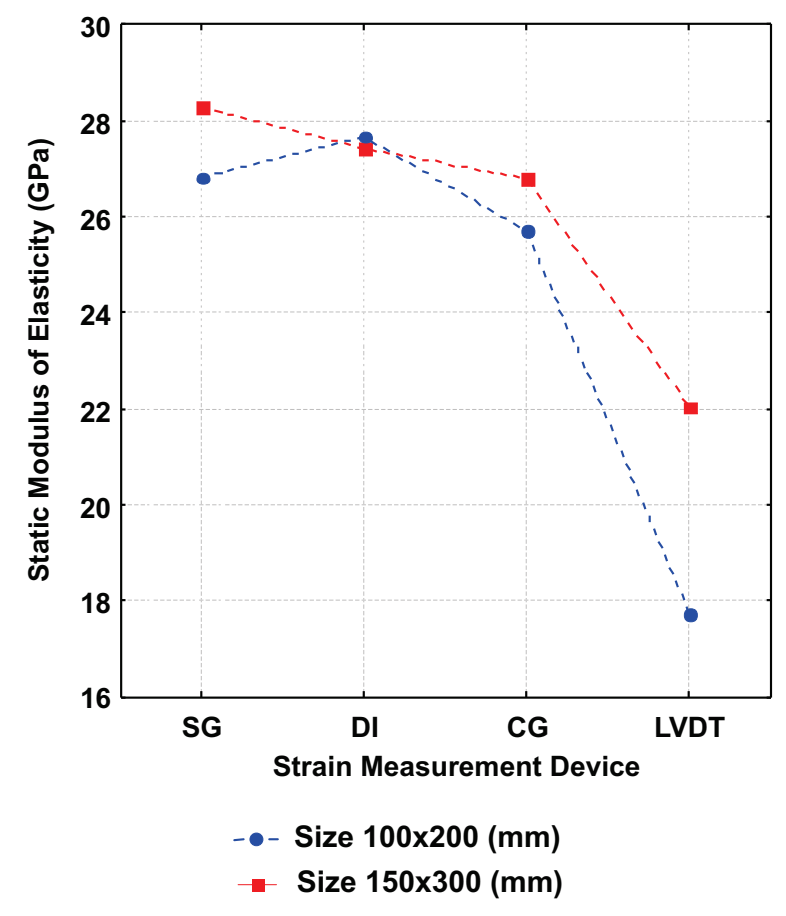

vices), and harder to use due to its analog readings, need of constant maintenance, equipment fragility, calibration difficulties and manual control by the testing operator.

7. In general, the strain gages and clip gages had more consistent readings and lowest coefficients of variation and showed important advantages such as a smaller need of external intervention during testing and minimization of reading errors by the operator. In case of strain gages, the bonding of the gage to the concrete surface has various aspects that should be closely watched, making its use more difficult. Also, the strain gages have to be discharged after their use, and a second use is not allowed, which increases testing costs. The clip gages have the advantage of measuring both longitudinal and transverse strains, show digital readings and are less susceptible to calibration procedures. Clip gages are more practical, can be reused several times and setting them up on the specimen is easy and no great operator expertise is required.

Modulus of elasticity tests using different measuring devices showed that even when following the criteria specified in code ABNT NBR 8522:2008 [3], variations in test results are relatively significant.

\section{Acknowledgements}

The authors wish to express special thanks to Laboratory Carlos Campos Consultoria e Construções Ltda., to Laboratório de Fur- 
nas Centrais Elétricas, to Realmix Concreto S.A., to Conselho Nacional de Desenvolvimento Científico e Tecnológico - CNPq and to Procad/CAPES.

\section{References}

[01] ASSOCIAÇÃO BRASILEIRA DE NORMAS TÉCNICAS - ABNT. NBR 5738: Concreto Procedimento para moldagem e cura de corpos de prova. Rio de Janeiro: ABNT, 2008.

[02] NBR 5739: Concreto - Ensaio de compressão de corpos de prova cilíndricos. Rio de Janeiro: ABNT, 2007.

[03] NBR 8522: Concreto - Determinação do módulo estático de elasticidade à compressão e Diagrama Tensão-Deformação - Método de Ensaio. Rio de Janeiro: ABNT, 2008.

[04] . NBR 6118: Projeto e Execução de Obras de Concreto Armado. Rio de Janeiro: ABNT, 2003.

[05] CUPERTINO, M. A.; PEREIRA, A. C; INÁCIO, J.J.; ANDRADE, M.A.S. Avaliação de Fatores de Ensaio que Interferem nos Resultados de Módulo de Elasticidade do Concreto. In: $49^{\circ}$ CONGRESSO BRASILEIRO DO CONCRETO, 2007, Bento Gonçalves - RS. Anais $49^{\circ}$ Congresso Brasileiro do Concreto. 2007. CD-ROM.

[06] MARTINS, D. G. Influência do tamanho do corpo de prova nos resultados de ensaios de módulo de deformação e resistência à compressão e suas correlações para concretos produzidos em GoiâniaGO [manuscrito] / Danilo Gomes Martins. - 2008. Dissertação (Mestrado) - Universidade Federal de Goiás, Escola de Engenharia Civil, 2008.

[07] RODRIGUES, G. S. S. Módulo de deformação estático do concreto pelo método ultra-sônico: estudo da correlação e fatores influentes. Dissertação de Mestrado. Escola de Engenharia Civil, Universidade Federal de Goiás. 2003. 234 p.

[08] ARAÚJO, SUÉLIO DA SILVA. Influência do tipo de medição na determinação do módulo estático de elasticidade do concreto - 2011. 212 f.: il., figs, tabs. Orientador: Prof. PhD. Gilson Natal Guimarães; Co-orientador: Prof. Dr. André Luiz Bortolacci Geyer. Dissertação (Mestrado) - Universidade Federal de Goiás, Escola de Engenharia Civil, 2011.

[09] FIGUEIREDO, E. J. P.; SOUZA, F. L. S.; DE FIGUEIREDO, A. D. Medidas de deformação através de strain gages. Trabalho da disciplina de tecnologia avançada no estudo do comportamento do concreto. São Paulo, 1989. 57 p.

[10] METHA, P. K.; MONTEIRO, Paulo J. M. "Concreto-Microestrutura, Propriedades e Materiais." $1^{\text {a }}$ Ed. Português, IBRACON, São Paulo, 2008.

[11] MONTIJA, Fernando Celloto. Aspectos da Variabilidade Experimental do Ensaio de Módulo de Deformação do Concreto. 2007. Dissertação (Mestrado em Engenharia de Construção Civil e Urbana) - Escola Politécnica, Universidade de São Paulo, São Paulo, 2007.
[12] SHEHATA, L. D. Deformações Instantâneas do Concreto. In: IBRACON, Concreto: Ensino, Pesquisa e Realizações. Editor: ISAIA, G. S. IBRACON, São Paulo, 2005. cap. 21, p. 633-654. ISBN 85-98576-03-4.

[13] . NBR 8953 - Concreto para fins estruturais - Classificação por grupos de resistência. Rio de Janeiro, 2009

[14] BARBOSA, Isa Lorena Silva. Influência dos agregados graúdos da região de Goiânia no módulo de deformação tangente inicial do concreto - 2009. 133 f.: il., figs, tabs. Orientador: Prof. Dr. André Bortolacci Geyer. Dissertação (Mestrado) Universidade Federal de Goiás, Escola de Engenharia Civil, 2009.

[15] PORTNOI, M. Extensometria: história, usos e aparelhos. Disponível em: http://locksmith.orcishweb.com/academic-files/ extensometria.html\# Toc511736064. Acesso em 15 jun. 2009.

[16] UNIVERSITY OF COLORADO AT BOULDER Transducers. 1999. Disponível em: http://civil.colorado.edu/courseware/struct_labs/ transducer.html. Acesso em 15 jun. 2011. 